\title{
Proteolysis of shrimp by-products (Peaneus monodon) from Madagascar Proteólisis de derivados de langostino (Peaneus monodon) de
Madagascar
}

Z. Randriamahatody, ${ }^{\mathrm{a}, \mathrm{c}}$, K. S.B. Sylla ${ }^{\mathrm{a}}$, H. T.M. Nguyen ${ }^{\mathrm{a}}$, C. Donnay-Moreno ${ }^{\mathrm{a}}$, L. Razanamparany ${ }^{\mathrm{c}}$, N. Bourgougnon ${ }^{b} \&$ J. P. Bergé ${ }^{a}$, *

\begin{abstract}
a Laboratoire de Science et Technologie de la Biomasse Marines IFREMER BP 21105, 44311 Nantes cedex 03, France

' Laboratoire de Biotechnologie et Chimie Marines, EA 2594, Université de Bretagne Sud, Campus de Tohannic, Centre de recherche Yves Coppens, Vannes, 56017, France

' Laboratoire de Biochimie Appliquée aux Sciences de I'Alimentation et à la Nutrition, Faculté des Sciences, Université d'Antananarivo, BP 906, Antananarivo, 101, Madagascar
\end{abstract}

*: Corresponding author : Jean-Pascal Bergé, Tel +33 240374079, Fax +33 240374071 email address : jpberge@ifremer.fr

\begin{abstract}
:
To generate and recover elements from shrimp heads, proteolysis was performed with commercial acidic or alkaline proteases for $22 \mathrm{~h}$. The resulting phases were characterized for protein and lipid content and amino acid composition while the molecular profiles of soluble peptides were established. Whatever the protease used, more than the half of the initial dry matter was found into aqueous phase including most of the proteins while lipids were found to remain insoluble. Hydrolysates were mainly constituted by small peptides (>80\% below $1000 \mathrm{Da}$ ) with up to $14 i \mathrm{i} 15$ amino acids identified. Moreover, all the hydrolyses have led to an increase of the amount of essential amino acids into the hydrolysates, including lysine. Thus, such proteolysis of shrimp heads can increase their potential nutritional value (small peptides with high content in essential amino acids) while allowing the concentration of lipids into insoluble phase and a partial demineralisation of the exoskeleton.
\end{abstract}

Para crear y recuperar elementos de las cabezas de langostino se llevó a cabo una proteólisis con proteasas ácidas y alcalinas comerciales durante 22 horas. Las fases resultantes se caracterizaron por contenido proteico y lípidico, composición de aminoácidos, mientras los perfiles moleculares de péptidos solubles fueron establecidos. Cualquiera fuese la proteólisis, más de la mitad de la materia seca inicial se encontró en fase acuosa, incluida la mayor parte de las proteínas, mientras los lípidos resultaron mantenerse insolubles. Los hidrolizatos estuvieron constituidos principalmente por pequeños péptidos (>80\% por debajo $1000 \mathrm{Da}$ ) con hasta $14 і ̈ 15$ aminoácidos identificados. Es más, todas las hidrólisis llevaron a un incremento de la cantidad de aminoácidos esenciales en los hidrolizatos, incluido lisina. Así, dicha proteólisis de cabezas de langostino puede incrementar de este modo su valor nutricional potencial (pequeños péptidos con un alto contenido en aminoácidos esenciales) mientras permite la concentración de lípidos en pase soluble y una desmineralización parcial de esqueleto externo.

Keywords : by-products ; shrimp; proteolysis ; hydrolysate

Palabras clave : derivados ; langostino; proteólisis ; hidrolizato 


\section{Introduction}

Worldwide fishery production was reported to be about 144 million tonnes in $2006,36 \%$ of which was from aquaculture, and approximately $33 \%$ are used for non-food purpose. Shrimp constitutes the main fish traded in value term with $16 \%$ of the total value of internationally traded fishery products (Food and Agriculture Organization [FAO], 2009).

In Madagascar, shrimp exportation constitutes $73 \%$ of the total fisheries product. The average of production is 12,977 tonnes in 2006 , including $51 \%$ of contribution from cultivated shrimp (Mission Economique de Tananarive, 2008).

Shrimp transformation lead to wastes generation. In Madagascar, they are composted to fertilizer or used in animal feeding; industrial transformation contributes only to about $10 \%$ of those products. These wastes are mainly constituted by cephalothorax and exoskeleton which represent at least $40 \%$ of the whole shrimp. Many studies have revealed that they contain useful components like proteins, lipids, astaxanthin and of course chitin, which is well known as a marketable product (Heu et al., 2003). Indeed, numerous works have been conduced for recovering those valuable products. Chemical procedures were developed to extract chitin and chitosan (Sagheer et al., 2009) and astaxanthin (Sachindra \& Mahendrakar, 2005; Sachindra, Bhaskar \& Mahendrakar, 2006). Fermentation and silage were experienced to recover chitin (Beaney, Lizardi-Mendoza \& Healy, 2005; Bhaskar, Suresh, Sakhare \& Sachindra, 2007; Rao, Munoz \& Stevens, 2000), astaxanthin (Cira, Huerta, Hall \& Shirai, 2002; Fagbenro \& Bello-Olusoji, 1997; M. Healy, Green \& A Healy, 2003) but also for animal feeding (Oliveira Cavalheiro, Oliveira de Souza \& Bora, 2007). Enzymatic hydrolysis was used for chitin extraction (Ferrer et al., 1996; Gagné \& Simpson, 1993; Gildberg \& Stenberg, 2001; Synowiecki \& Al-Khateeb, 2000), for carotenoprotein recovering (Babu, Chakrabarti \& Surya Sambasivarao, 2008; Simpson \& Haard, 1985), and for generation of bioactive or functional peptides (He, Chen, Sun, Zhang \& Gao, 2006; Ravallec-Plé \& Van Wormhoudt, 2003; Ruttanapornvareesakul et al., 2005; Ruttanapornvareesakul et al., 2006).

Proteins represent the major component of shrimp heads (Fagbenro \& Bello-Olusoji, 1997; Cira et al., 2002; Rutanapornvareesakul et al., 2005; Coward-Kelly, Agbogbo \& Holtzapple, 2006; Babu et al., 2008; Limam, Sadok \& El Abed, 2008). Enzymatic proteolysis is an attractive means of producing protein concentrates with interesting nutritional properties from by-products. Most of the time, hydrolysis of marine by-products are conduced by using, large spectra proteases that work in neutral or alkaline environment as their effectiveness of protein recovery and peptides generation were largely reported. However, in the case of hard tissues like the exoskeleton of crustacean such processing conditions may be not sufficient to recover additional valuable component as the chitin for example.

The objective of this study was to check the effectiveness of proteases that work at extreme $\mathrm{pH}$ (over 9 or below 4) on matter solubilization and distribution and to produce valuable fractions that could be further upgraded. Long term proteolysis (22 hours) was thus conduced with 4 proteases, 2 acidic ones (pepsin and Novozym 37020) and 2 alkaline ones (Protex 6L and Delvolase). 


\section{Material and methods}

\subsection{Materials}

\subsubsection{Raw material}

Heads of frozen aquaculture shrimp (Penaeus monodon, Family: Panaeidae, Order: Decapoda, Class: Malacostraca, Phylum: Arthropoda) were collected from a processing factory (UNIMA®, Madagascar) on August 2005. They were packed in plastic bags and stored at i $20^{\circ} \mathrm{C}$ until use. Maximal time of storage was 3 months.

\subsubsection{External enzymes}

All the enzymes used here are endopeptidase ones.

Pepsin from porcine stomach mucosa (EC 3.4.23.1) was purchased from Sigma Aldrich (Steinheim, Germany).

Novozym 37020 is a large spectra protease produced by fermentation, it was provided by Novozymes (Bagsvaerd, Denmark).

Protex 6L (EC 3.4.21.62) is an alkaline serine endopeptidase derived from a selected strain of $B$. licheniformis, it was provided by Genecor International (New York, USA).

Delvolase (E.C 3.4.21.14) is an industrial enzyme mixture from DSM Food Specialties (Seclin, France); the main constituent is a serine protease made from Bacillus licheniformis.

\subsection{Hydrolysis}

Figure 1 outlines the overall process employed in the production of shrimp head hydrolysates. The frozen and minced shrimp heads were stored overnight at $4^{\circ} \mathrm{C}$ for thawing and homogenized with MilliQ-purified water (ratio 1:1, w/v). For each hydrolysis, $100 \mathrm{~g}$ sample head were used. The mixture was directly poured into a $300 \mathrm{~mL}$ closed glass vessel with a double jacket to enable thermal exchanges (heating or cooling). In order to ensure a good proteolysis and despite the lack of data on this substrate, hydrolysis reactions were performed at $\mathrm{pH}$ and temperature known to be optimal for enzyme activity on reference molecules: Pepsin: $\mathrm{pH} \mathrm{2,} 40{ }^{\circ} \mathrm{C}$; Novozym 37020: $\mathrm{pH} \mathrm{3,} 50^{\circ} \mathrm{C}$; Protex $6 \mathrm{~L}$ : $\mathrm{pH} 9.5,60{ }^{\circ} \mathrm{C}$; Delvolase: $\mathrm{pH} 10,60^{\circ} \mathrm{C}$. Before hydrolysis, mixing was performed for an initial 15 min to adjust the $\mathrm{pH}$ (by adding $1 \mathrm{M} \mathrm{HCl}$ or $2 \mathrm{M} \mathrm{NaOH}$ ) and to obtain the desired temperature (using a water bath). Hydrolysis was initiated by adding enzymes. Due to the difference of specific activity of enzymes, different ratio enzyme/substrat were used to counterbalance those variations.Thus, $5 \mathrm{~g} / \mathrm{kg}$ of Pepsin or Novozym 37020; $10 \mathrm{~g} / \mathrm{kg}$ of Protex $6 \mathrm{~L}$ and $20 \mathrm{~g} / \mathrm{kg}$ of Delvolase were adopted. The mixtures were continuously stirred at $300 \mathrm{rpm}$ for 24 hours. Temperature and $\mathrm{pH}$ were regulated (by using $2 \mathrm{M} \mathrm{HCl}$ or $2 \mathrm{M} \mathrm{NaOH}$ ).

The degree of hydrolysis (DH) is defined as the \% of peptide bonds cleaved during the enzymatic reaction. There is proportionality between the number of peptide bonds cleaved and the acid or base consumption which is given by the following equation:

$$
\% \mathrm{DH}=h / h_{\text {tot }} \times 100
$$


where, h, number of peptide bonds broken; $h_{t o t}=8.6 \mathrm{meq} / \mathrm{g}$, total number of peptide bonds in substrate (Adler-Nissen, 1986).

According to Adler-Nissen (1977), when the reaction $\mathrm{pH}$ is above the $\mathrm{pK}_{\mathrm{a}}$ of the $\alpha-\mathrm{NH}$ group, then the equation is:

$$
\% \mathrm{DH}=h / h_{\text {tot }} \times 100=\left(B \mathrm{~N}_{\mathrm{b}} / \alpha h_{\text {tot }} \mathrm{MP}\right) \times 100
$$

where $\mathrm{B}=\mathrm{X} \mathrm{ml}$, base consumption in $\mathrm{ml} ; \mathrm{N}_{\mathrm{b}}=2 \mathrm{~N} \mathrm{NaOH}$, normality of the base; $\alpha \square$ is the average degree of dissociation of the $\alpha-\mathrm{NH}$ groups (see below); MP is the mass of protein in grams (N x 6.25) (Adler-Nissen, 1977).

According to Zhao et al.(1996), when the reaction $\mathrm{pH}$ is below the $\mathrm{pK}_{\mathrm{a}}$ of the $\alpha-\mathrm{NH}$ group, the $\mathrm{DH}$ value can be estimated from the equation

$$
\% \mathrm{DH}=h / h_{\text {tot }} \times 100=\left(A \mathrm{~N}_{\mathrm{a}} /(1-\alpha) h_{\text {tot }} \mathrm{MP}\right) \times 100
$$

where $A$ is the acid consumption in $\mathrm{ml}, \mathrm{N}_{\mathrm{a}}$ is the normality of the acid, $\alpha$ and MP are similar as above (Zhao, Sannier \& Piot, 1996).

The degree of dissociation was found in the following way

$$
\alpha=\left(10^{\mathrm{pH}-\mathrm{pK})} /\left(1+10^{\mathrm{pH}-\mathrm{pK}}\right)\right.
$$

The pK values at different temperatures $\mathrm{T}$ (Kelvin) were calculated from Steinhard and Beychok (1964):

$$
\mathrm{pK}=7.8+\frac{(298-T)}{298 T} \times 2400
$$

After 22 hours (1335 min), hydrolysis were stopped by enzyme inactivation: addition of $5 \mathrm{M}$ $\mathrm{NaOH}$ to reach neutrality for Pepsin; heating at $85^{\circ} \mathrm{C}$ for 25 min for Novozym $37020,85^{\circ} \mathrm{C}$ for $20 \mathrm{~min}$ for Protex $6 \mathrm{~L}$ and $90{ }^{\circ} \mathrm{C}$ for $20 \mathrm{~min}$ for Delvolase. After cooling at room temperature, the hydrolysates were centrifuged at $10.000 \mathrm{~g}$ for $20 \mathrm{~min}$. Two fractions were thus collected: the insoluble sludge and the soluble aqueous phase. Each fraction was then freeze-dried and stored at i $20^{\circ} \mathrm{C}$ until further analyses.

\subsection{Chemical analysis}

All the analyses were performed in triplicate except the amino acid profile and the molecular weight distribution.

Moisture content was determined by oven drying samples at $105^{\circ} \mathrm{C}$ until constant weight (Association of Official Analytical Chemists [AOAC], 2005). Ash content was carried out by ignition of samples at $600{ }^{\circ} \mathrm{C}$ for $24 \mathrm{~h}$ (AOAC, 2005). The total nitrogen content of the nonhydrolyzed raw material, aqueous phase and insoluble sludge generated by hydrolysis was determined using the Kjeldahl method (Crooke \& Simpson, 1971). Crude protein was estimated by multiplying the total nitrogen content $(\% \mathrm{~N})$ by the factor 6.25 .

Amino acid composition was determined for the raw (nonï hydrolysed) material and hydrolysates according to a previous study (Kechaou et al., 2009). Briefly, ten milligrams of freeze-dried samples were previously digested with $\mathrm{HCl}$ under nitrogen atmosphere for 18 hours. Then, the samples were completely dried under a nitrogen atmosphere and subsequently diluted by adding $2.5 \mathrm{ml}$ water. The amino acid analysis was thus performed using the EZ:faastÊ procedure (Penomenex, USA) consisting of a solid phase extraction 
step followed by derivatization and liquid/liquid extraction. An aliquot of the organic phase was analysed on a GC-FID system (Perkin Elmer Autosystem XL). The injector temperature was maintained at $250{ }^{\circ} \mathrm{C}$ while detection occurred at $320{ }^{\circ} \mathrm{C}$. Separation was achieved using a Zebro ZB-AAA GC column $(10 \mathrm{~m} \times 0.25 \mathrm{~mm})$ with he oven temperature linearly increasing from 110 to $320{ }^{\circ} \mathrm{C}$ at $32^{\circ} \mathrm{C} / \mathrm{min}$. Helium was employed as the carrier gas at a constant flow rate of $1.5 \mathrm{~mL} / \mathrm{min}$. The amino acids were quantified by their response factor relative to the internal standard norvaline added at a concentration of $200 \mu \mathrm{mol} / \mathrm{L}$.

Lipids were extracted according to the Folch procedure (Folch, Lees \& Stanley, 1957). Total lipid content was determined gravimetrically after solvent extraction and evaporation.

\subsection{Determination of Molecular Weight}

The molecular weight distribution of peptides in the hydrolysates was analysed by gel filtration chromatography. The molecular weight fractions were separated using a high performance liquid chromatography (HPLC) system equipped with a size exclusion column (Superdex peptide 10/300 GL). The mobile phase consisted of water with trifluoroacetic $1 \mathrm{~g} / \mathrm{L}$ and acetonitrile $5 \mathrm{~g} / \mathrm{L}(70: 30)$, the flow rate was $0.5 \mathrm{~mL} / \mathrm{min}$. The chromatography was monitored by measuring the absorbance at $214 \mathrm{~nm}$. The column was calibrated with standards: Ribonuclease A (13700 Da), Aprotinin (6500 Da), Renin (1760 Da), Vasopressine $(1084 \mathrm{Da})$ and Leucine $(294 \mathrm{Da})$. The molecular weight ranges of the different fractions were based on the retention times of the collected fractions and determined from a standard curve.

\subsection{Statistical analysis}

All data presented are means \pm standard deviations. Analysis of variance (One way ANOVA) were performed by Statgraphics Plus version 5.1 (Manugistics Inc., USA). The method used to discriminate among means was Fisher $\hat{\mathbf{S}}$ least significant difference (LSD) procedure. Mean were accepted as significantly different at $95 \%$ level ( $p$ Ò 0.05 ).

\section{Results and discussion}

Without any antimicrobial treatment (of the raw material and during the hydrolysis) bacterial proliferation may have occurred. Microbial compounds that can be microbially formed during the process may affect the global odour of the products (due to complex mixtures of volatile compounds such as unsaturated carbonyl compounds and alcohols with 6, 8 or 9 carbon atoms). However, non significant modification of the overall aroma was percept even after 22 hours of hydrolysis confirming a reduced bacterial proliferation under such conditions of hydrolysis.

\subsection{Proximal composition of shrimp head}

On dry weight basis, proteins were found to be the major constituents of shrimp head $(49.1 \pm$ $0.9 \%)$ while lipids and ashes were equivalent and represented around 17-19\% (16.6 $\pm 0.2 \%$ and $18.7 \pm 0.1 \%$ respectively). Chitin was considered as the residue and thus estimated to be around $16 \%$. 


\subsection{Degree of hydrolysis}

During hydrolysis, shrimp head turned into a free flowing liquid. Hydrolytic curves corresponding to Pepsin, Novozym 37020, Protex 6L and Delvolase are reported in Figure 2. Whatever the enzyme used, first order kinetics was observed with an initial rapid phase where a large number of peptides bonds are broken (rapid consumption of $\mathrm{HCl}$ or $\mathrm{NaOH}$ ), followed by a decreased rate of hydrolysis and finally approaching a stationary phase where no apparent hydrolysis takes place. Such hydrolysis curves are similar to those previously published on herring muscle and head (Liceaga-Gesualdo \& Li-Chan, 1999; Sathivel et al., 2003), salmon head (Gbogouri, Linder, Fanni \& Parmentier, 2004; Sathivel, Smiley, Prinyawiwatkul \& Bechtel, 2005) and cuttlefish and sardine viscera (Dumay, Donnay-Moreno, Barnathan, Bergé \& Jaouen, 2006; Kechaou et al., 2009) for example. At higher \%DH, product inhibition may occur due to the high concentration of soluble peptides that can act as effective substrate competitors (Weil, 2005).

After 22 hours of hydrolysis, \%DH varied from 18.6\%DH (Protex 6L) to 36.5\%DH (Pepsin). Such results are in accordance with previous proteolysis conduced on marine substrates like shrimp discards $(\% \mathrm{DH}=30 \%$ with Alcalase; Synowiecki \& Al-Khateeb, 2000) or sardine heads $(\% \mathrm{DH}=20 \%$ with Protamex; Dumay et al., 2006).

Regarding the kinetics, in our conditions, Pepsin was found to be the most efficient in hydrolysing shrimp head leading to the highest \%DH but also reaching $33.5 \% \mathrm{DH}$ in less than 3 hours (167 min). Thus, among the four enzymes tested here, Pepsin was the most performing enzyme in term of proteolysis (peptidic bond broken) and reaction rate (time of proteolysis). Despite a lowest maximal \%DH (22.3\%DH) at the end, Novozym 37020 appeared to be second most efficient enzyme as, after 3 hours, $17.9 \% \mathrm{DH}$ was observed ( $92 \%$ of the final value). Both of these enzymes are acidic ones which could explain their highest proteolytic activities on shrimp heads. It is well known that protein solubility and conformation is influenced by $\mathrm{pH}$ condition: each protein has an isoelectric $\mathrm{pH}$ where their insolubility is maximal. As far as the $\mathrm{pH}$ condition is different of isoelectric $\mathrm{pH}$ of the proteins, their solubility is increased, improving their capacity to interact with the enzyme. Some proteins, like glutenin for example, have a maximal solubility at $\mathrm{pH} 2$ or $\mathrm{pH} 12$. Our results suggest that shrimp head proteins are glutenin-like as far as isoelectric $\mathrm{pH}$ is concerned.

For the alkaline proteases Protex $6 \mathrm{~L}$ and Delvolase, lowest efficiencies (18.6 and $23.7 \% \mathrm{DH}$ ) and reaction rates (73.5 and $56.2 \%$ of the final value after 3 hours) were obtained. Moreover, even after 22 hours proteolysis seemed to continue as little increases of \%DH were observed.

\subsection{Dry matter distribution}

Without hydrolysis (i.e. in the crude head shrimp), after the centrifugation step, only $31.6 \%$ of dry matter was located into the soluble phase while $68.4 \%$ remained insoluble (Figure 3 ). After conducting hydrolysis on shrimp head samples, the dry matter distribution was mainly located in the supernatant, regardless to the enzyme used. This illustrates the solubilization of the matter under the action of the proteases as previously noticed notably on marine byproducts (Aspmo, Horn \& Eusink, 2005; Dumay et al., 2006; Kechaou et al., 2009). However, slight differences were observed according to the enzyme. Indeed, Protex $6 \mathrm{~L}$ and Pepsin were found to be the most efficient in terms of dry matter solubilization with 64.1 and $63.5 \%$ of dry matter located in supernatant phase after hydrolysis while Novozym 37020 and Delvolase have completed only $53.5 \%$ and $51.6 \%$ of solubilization respectively. However, it is important to notice that despite the long time of hydrolysis (22 hours), at least $36 \%$ of shrimp head remained insoluble due to the presence of exoskeleton which are not easily hydrolysed. However, as previously noticed, such insoluble phases are of interest due to 
their content in non modified chitin that can be easily recovered from sludge by classical chemical methods (Gildberg \& Stenberg, 1991; Gildberg \& Stenberg, 2001).

In our conditions, slights increases of salts (from 3 to $6.2 \%$ ) were observed due to $\mathrm{pH}$ regulation of proteolysis by $\mathrm{NaOH}$ or $\mathrm{HCl}$

\subsection{Proximate composition}

The average chemical composition (based on triplicates) of the freeze-dried soluble and insoluble fractions after 22 hours of hydrolysis are presented on Table 1. Regardless to the enzyme used, according to statistical analysis, supernatants were found to be rich in protein $(48.1$ to $64.7 \%)$ and poor in lipid (1.2 to $3.8 \%)$. As expected, those results illustrate the effectiveness of proteases to solubilize proteins but such enzymes seem here ineffective to recover lipids of shrimp heads into the resulting the soluble phases.

Such high levels of protein recovery into soluble phase have been previously observed either for hydrolysates of shrimp discards (Synowiecki \& Al-Khateeb, 2000), for shrimp head silage (Oliveira Cavalheiro et al., 2007) and after fermentation of shrimp biowaste (Bueno-Solano et al., 2009). However, in some cases, higher protein recovery rates have been obtained (69 to $91 \%$ on dry weight basis) (Gildberg \& Stenberg, 2001; Ruttanapornvareesakul et al., 2005; Limam et al., 2008) which could be due to biochemical differences (proximate composition of raw material) and processing conditions (enzyme type, temperature, pHé ) as previously noticed (Slyzite, Dauksas, Falch, Storro \& Rustad, 2005, Dumay et al., 2006).

The few amounts of lipid into the supernatants are in accordance with previous studies on shrimp waste hydrolysates where less than $1 \%$ of lipids were quantified (Gildberg \& Stenberg, 2001; Ruttanapornvareesakul et al., 2006). Regardless to the enzyme used, the major part of lipids remained into the sludge $(95.7,88.9,78.1$ and $84.5 \%$ for Pepsin, Novozym 37020, Protex 6L and Delvolase respectively).

Regarding the ash content of the supernatant, it ranged from $24 \%$ (Delvolase) to $41 \%$ (Pepsin). According to enzyme used, ash contents are significantly different (P Ò 0.05). Anyway, hydrolysis under acidic $\mathrm{pH}$ led to hydrolysates richer in minerals (33\% and $41 \%$ respectively for Novozym 37020 and Pepsin) while proteolysis under alkaline conditions led to a lower level of minerals (24\% and $29 \%$ respectively for Protex $6 \mathrm{~L}$ and Delvolase). Such results are expected as it is well known that demineralisation of shrimp carapace occurs at low $\mathrm{pH}$ and this is the basis of the chitin extraction by chemical treatments (Cauchie, JasparVersali, Hoffmann \& Thomé, 2002; Paulino, Simionato, Garcia \& Nozaki, 2006; Pillai, Paul \& Sharma, 2009; Sagheer, Al-Sughayer, Muslim \& Elsabee, 2009; Yen, Yang \& Mau, 2009) or by fermentation process (Bhaskar et al., 2007; Cira et al., 2002; Jung, Kuk, Kim \& Park, 2005; Pacheco et al., 2009). In addition, low pH increases the solubility of insoluble salt of Calcium (Jung \& Kim, 2007). It has to be noticed that, as expected, addition of acid or alkaline during hydrolysis increases ash content in hydrolysates (Thiansilakul, Benjakul \& Shahidi, 2007). Indeed, regarding to the $\mathrm{DH}$ which is related to the quantity of acid or alkaline added, Pepsin which induced to the highest DH generated the hydrolysate richest in ash. Inversely, hydrolysis with Protex 6L produced the hydrolysate poorest in ash, while the DH obtained was the lowest.

Such long time hydrolysis have lead to a protein enrichment of the supernatants (Pepsin except) and a great reduction of their fat contents. Indeed, by comparison to non-hydrolysed material, the lipid amount into supernatant was reduced by up to 16 with Pepsin (16.6 g of lipid per $100 \mathrm{~g}$ of dry head and $1.4 \mathrm{~g}$ of lipid per $100 \mathrm{~g}$ of supernatant). This factor reduction is around 5 for the other enzymes (Novozym 37020, Protex 6L and Delvolase). However, such proteolysis and notably the one under acidic conditions have lead to a mineral 
enrichment of the soluble phases. Consequently, the resulting sludges were found to be poorer in proteins and richer in lipids by comparison to raw material. This confirms that such proteolysis can lead to very different fractions on a biochemical point of view.

\subsection{Nitrogen recovery}

Nitrogen recovery indicates the percentage of nitrogen solubilized into hydrolysate to total nitrogen in the raw material (Figure 4). After $22 \mathrm{~h}$ of hydrolysis, the amounts of soluble nitrogen were 79.5, 73.9, 70.3\% and 54.9 with Protex 6L, Pepsin, Delvolase and Novozym 37020 respectively.

Such levels of nitrogen recovery are in accordance with those previously observed in similar studies on shrimp head (Gildberg \& Steinberg 2001; Ruttanapornvareesakul et al., 2005; Limam et al., 2008) but also on other kind of marine material like fish (Kristinsson \& Rasco, 2000, Jung \& Kim, 2007), cuttlefish and sardine (Kechaou et al., 2009). This illustrates how proteases can be efficient for recovering soluble nitrogen by breaking peptidic bonds but at various rates.

By comparison to the observed \%DH (see above) some discrepancies appear here due to the fact that \%DH do not reflect the protein solubilization but give the proportion of peptidic bonds cleaved under protease actions. Thus, if Pepsin was found to be an efficient enzyme for cleaving bonds or recovering the proteins this was not the case for Protex $6 \mathrm{~L}$ which was found to be the best for cleaving but the worst for recovering nitrogen. This illustrates the complementarities between those 2 indicators and the capacities of the proteases to clived or not peptidic bonds of already solubilized proteins leading to the reduction of the molecular size distribution of the soluble peptides. As all those enzymes are endoproteases, cliving peptidic bond will in some case be not sufficient to induce a higher nitrogen recovery as the resulting peptides are not small enough to become soluble after centrifugation.

Some authors have observed that, during shrimp biowaste fermentation, protein solubilization was enhanced at higher pH (Bhaskar et al., 2007; Rao et al., 2000). This is partially confirm here where the alkaline proteases (Protex $6 \mathrm{~L}$ and Delvolase) were found efficient while Novozym 37020 not. However, Pepsin which has worked at $\mathrm{pH}=2$ counterbalance this. Further studies are thus needed to confirm or not such $\mathrm{pH}$ influence.

\subsection{Molecular weight}

Shrimp head hydrolysates were separated using gel chromatography to compare their peptide size composition. The resulting chromatogram of Pepsin hydrolysate is presented on Figure 5 as an example. The data treatment of those chromatograms (area under the curve) is presented on Figure 6.

Enzymatic hydrolysis of shrimp head has enhanced the solubility of proteins but has also cut them into shorter peptides. Indeed, 82.5 to $92.7 \%$ of soluble peptides had a molecular weight below $1000 \mathrm{Da}$ and 38.1 to $49.6 \%$ had their molecular weights ranging from 250 to $500 \mathrm{Da}$. However, regarding to the enzyme used, slight differences can be noticed. Indeed, after 22 hours of proteolysis with Delvolase, less than $2 \%$ of the soluble peptides were found bigger than $2000 \mathrm{Da}$ while 3 times more were quantified into Pepsin supernatant. (7.5\%). With Protex $6 \mathrm{~L}$, up to $17 \%$ of peptides under $250 \mathrm{Da}$ were detected while they represented less than $10 \%$ in Delvolaseôsoluble phase. Those results are similar to some previous studies with shrimp head hydrolysate where the major peptides were found between 1400 to $300 \mathrm{Da}$ (Ruttanapornvareesakul et al., 2006). 
It is well known that the smaller the peptides are, the highest their absorption by the intestinal tract will be (He et al., 2006; Plascencia-Jatomea, Olvera-Novoa, Arredondo-Figueroa, Hal \& Shirai, 2002). In addition, numerous short chain peptides have been identified, notably into marine hydrolysates, for their biological properties (Chabeaud et al., 2009; He et al., 2006; Je, Park, Kwon \& Kim, 2004; Je, Qian, Byun \& Kim, 2007; Ravallec-Plé \& Van Wormhoudt, 2003). Thus, such enzymatic hydrolysis can be a good way of upgrading shrimp heads by producing hydrolysates rich in small peptides for nutritional and biological purposes.

\subsection{Amino acid composition}

The total amino-acid compositions of raw material and the 4 hydrolysates after 22 hourhydrolysis are presented in Table 2.

As expected, the proteolysis has lead to an amino acid enrichment in the supernatant by comparison to the soluble phase recovered after centrifugation of the raw material. Indeed, starting with $177 \mathrm{mg}$ of amino acid per gram of dry weight, up to $398 \mathrm{mg}$ were obtained into the Protex $6 \mathrm{~L}$ supernatant. However, this enrichment was not similar whatever the enzymes, as only $239 \mathrm{mg}$ were quantified into the Novozym 37020 supernatant, 271 and $303 \mathrm{mg}$ into the Pepsin and Delvolase ones (and $398 \mathrm{mg}$ into the Protex $6 \mathrm{~L}$ one). Those results fit with nitrogen recovery rates as the nitrogen is mostly under the peptidic form.

From 14 to 15 different amino acids were detected into those different fractions as in some cases, some amino acids were not anymore detected into the soluble phases (Methionine with Novozym 37020 and Histidine with Protex 6L). It is reported that alkaline condition at pH under 9.5 may lead to the desamination of basic amino acids. Histidine destruction after hydrolysis with Protex $6 \mathrm{~L}$ may result from that. However, with or without proteolysis, and whatever the enzyme, the proportion of essential amino acids (EAA) was found to be stable, between 35 to $40 \%$. 8 essential amino acids were identified in raw material and shrimp heads hydrolysates. Tryptophane was not identified as well as cysteine which is conditionally essential for the reason that it is needed at high amounts in some physiopathological circumstance. The absence of tryptophan in shrimp heads and shrimp heads hydrolysates is explained by its destruction at acidic condition during amino acid analysis. Cystein is sensitive to oxidation and under thermal treatment at alkaline condition, converted to dehydroalanine or lanthionine (Cheftel, Cuq \& Lorient, 1985). Those reactions may be responsible of the destruction of cysteine in shrimp heads and shrimp heads hydrolysates.

In terms of concentrations, in raw material and hydrolysates, more than $60 \%$ of the total amino acids were constituted by Glutamic acid (14ï 17\%), Aspartic acid (10-15\%), Glycine $(8-12 \%)$, Alanine (7-12\%), Leucine (8-9\%) and Proline (7-10\%). Such results are in accordance with previous results on shrimp biowaste hydrolysates (Armenta \& GuerreroLegarreta, 2009; Ruttanapornvareesakul et al., 2006; Synowiecki \& Al-Khateeb, 2000) where Aspartic acid and Glutamic acid were detected in high amounts. However, some discrepancies can be noticed regarding the enzyme. Indeed, the alkaline enzymes (Protex $6 \mathrm{~L}$ and Delvolase) were found to be the most efficient for the recovery of Methionine (increase factor of 7 and 5 respectively) and on Serine (increase factor of 4 and 3 respectively). At the opposite, Novozym 37020 seems to be non appropriate for the extraction of Methionine (not anymore detected) and Tyrosine, Alanine and Phenylalanine with lower values compared to raw material (this is also the case for Protex $6 \mathrm{~L}$ with Histidine).

Among the major amino acids detected into the 4 hydrolysates, some have an important nutritional interest. Indeed, Leucine is an essential one that has to be given into feed and foodstuffs while Glutamic acid, Aspartic acid, Alanine and Glycine are known to be flavour enhancers (Heu et al., 2003; Jung Nim, T Watanabe, Endoh, K Watanabe \& Abe, 2002). 
Moreover, the levels of EAA are in accordance with the nutritional recommendation of the FAO (Cao, Zhang, Hong \& Ji, 2008). At last, the increase of the Lysine content is of interest notably for feed purpose as this amino acid is the limiting one in cereals and has to be added notably in poultry feed.

These results indicate that shrimp head hydrolysates can be a good source of high nutritional quality products for feed or food purposes.

\section{Conclusion}

Proteolysis is well known to be a gentle method for recovering proteins from marine byproducts, and thus generate peptides with functional and biological activity, but also improving amino acid composition increasing that way the protein quality. Extraction of elements from hard tissues requires extreme environmental conditions. In this study, we have tried to gather the 2 hypothesis by conducting long time proteolysis with acidic or alkaline enzymes.

This study like previous ones confirms thus that enzymatic hydrolysis is an effective process to separate components from marine biomass for further upgrading. Whatever the protease used here, a great part of proteins was recovered in the aqueous phase as small size peptides with interesting level of essential amino acids. Variations were however observed regarding the enzymes used and notably the alkaline or the acidic ones. One of the main differences was on the mineral content of the resulting phases which validates that acidic proteases can help to recover calcium into aqueous solutions and thus contribute to increase the nutritional interest of such hydrolysates.

This study has confirmed that enzymatic hydrolysis could be a valuable upgrading process for shrimp wastes notably the head as it is quite simple to implement and because it generates rich protein hydrolysates with low fat content that can be useful for food and feed purpose. Additionally the insoluble fractions contain valuable component such as lipids, insoluble proteins and partially demineralised and deproteinised chitin that can be further separated.

\section{Acknowledgements}

The authors wish to thank AUF (Agence Universitaire pour la Francophonie) for their financial support.

This study is part of the actions conduced by the members of the SEA ${ }^{\text {PRO }}$ network (www.seapro.fr) which aims to promote a better use of the marine biomass with sustainable process. 


\section{References}

Adler-Nissen, J. (1977). Enzymic hydrolysis of food proteins. Process Biochemistry, 12, 1819.

Alder-Nissen, J., (1986). Enzymic hydrolysis of food proteins, Elsevier Applied Science Publishers, New York., U.S.A.

Aspmo, S.I., Horn S.J. \& Eusink, V.G.H. (2005). Enzymatic hydrolysis of Atlantic cod (Gadus morhua L.) viscera. Process Biochemistry, 40, 1957-1966.

Armenta, R.E \& Guerrero-Legarreta, I. (2009). amino acid profile and enhancement of the enzymatic hydrolysis of fermented shrimp carotenoproteins. Food Chemistry, 112, 310-315.

Babu, C.M., Chakrabarti, R. \& Surya Sambasivarao, K.R. (2008). Enzymatic isolation of carotenoid-protein complex from shrimp head waste and its use as a source of carotenoids. LWT - Food Science and Technology, 41, 227-235.

Beaney, P., Lizardi-Mendoza, J. \& Healy, M. (2005). Comparison of chitins produced by chemical and bioprocessing methods. Journal of Chemical Technology and Biotechnology, 80, 145-150.

Bhaskar, N., Suresh, P.V., Sakhare, P.Z. \& Sachindra, N.M. (2007). Shrimp biowaste fermentation with Pediococcus acidolactici CFR2182: Optimization of fermentation conditions by response surface methodology and effect of optimized conditions on deproteination/demineralization and carotenoid recovery. Enzyme and Microbial Technology, 40, 1427-1434.

Bueno-Solano, C., López-Cervantes, J., Campas-Baypoli, O.N., Lauterio-García, R., AdanBante, N.P. \& Sánchez-Machado, D.I. (2009). Chemical and biological characteristics of protein hydrolysates from fermented shrimp by-products. Food Chemistry, 112, 671-675.

Cao, W., Zhang, C., Hong, P. \& Ji, H. (2008). Response surface methodology for autolysis parameters optimization of shrimp head and amino acids released during autolysis. Food Chemistry, 109, 176-183.

Cauchie, H.-M., Jaspar-Versali, M.-F., Hoffmann, L. \& Thomé, J.-P. (2002). Potential of using Daphnia magna (Crustacea) developing in an aerated waste stabilisation pond as a commercial source of chitin. Aquaculture, 205, 103-117.

Chabeaud, A., Vandanjon, L., Bourseau, P., Jaouen, P., Chaplain-Derouiniot, M. \& Guérard, F.( 2009). Performances of ultrafiltration membranes for fractionating a fish protein hydrolysate: Application to the refining of bioactive peptidic fractions. Separation and Purification Technology, 66, 463-471.

Cheftel, J.C., Cuq, J.L \& Lorient, D. (1985). Protéines alimentaires [Food proteins]. Paris : Tec. et Doc. ed..

Cira, L.A., Huerta, S., Hall, G.M. \& Shirai, K. (2002). Pilot scale lactic acid fermentation of shrimp wastes for chitin recovery. Process Biochemistry, 37, 1359-1366.

Coward-Kelly, G., Agbogbo, F.K. \& Holtzapple, M.T. (2006). Lime treatment of shrimp head waste for the generation of highly digestible animal feed. Bioresource Technology, 97, 1515-1520.

Crooke, W.M. \& Simpson, W.E. (1971). Determination of ammonium in Kjeldhal digests of crops by an automated procedure. Journal of the Science of Food and Agriculture, 27, 1256-1262.

Dumay, J., Donnay-Moreno, C., Barnathan, G., Jaouen, P. \& Bergé, J.P. (2006). Improvement of lipid and phospholipid recoveries from sardine (Sardina pilchardus) viscera using industrial proteases. Process Biochemistry, 41, 2327-2332.

Fagbenro, O.A. \& Bello-Olusoji, O.A. (1997). Preparation, nutrient composition and digestibility of fermented shrimp head silage. Food Chemistry, 60, 489-493.

FAO. (2009). The state of world fisheries and aquaculture 2008. Retrieved from FAO website: ftp://ftp.fao.org/docrep/fao/011/i0250e/i0250e.pdf 
Ferrer, J., Paez, G., Marmol, Z., Ramones, E., Garcia, H. \& Forster, C.F. (1996). Acid hydrolysis of shrimp-shell wastes and the production of single cell protein from the hydrolysate. Bioresource Technology, 57, 55-60.

Folch, J., Lees, M. \& Stanley, G.H.S. (1957). A simple method for the isolation and purification of total lipids from animal tissues. Journal of Biological Chemistry 226, 497-509.

Gagné, L.A. \& Simpson, B.K. (1993). Use of proteolytic enzymes to facilitate the recovery of chitin from shrimp wastes. Food Biotechnology, 7, 253-263.

Gbogouri, G.A., Linder, M., Fanni, J. \& Parmentier, M. (2004). Influence of hydrolysis degree on the functional properties of salmon by-products hydrolysates. Journal of Food Science, 69, C615-C622.

Gildberg, A. \& Stenberg, E. (2001). A new process for advanced utilisation of shrimp waste. Process Biochemistry, 36, 809-812.

He, H., Chen, X., Sun, C., Zhang, Y. \& Gao, P. (2006). Preparation and functional evaluation of oligopeptide-enriched hydrolysate from shrimp (Acetes chinensis) treated with crude protease from Bacillus sp. SM98011. Bioresource Technology, 97, 385-390.

Healy, M., Green, A. \& Healy, A. (2003). Bioprocessing of marine crustacean shell waste. Acta Biotechnologica, 23, 151-160.

Heu, M.-S., Kim, J.-S. \& Shahidi, F. (2003). Components and nutritional quality of shrimp processing by-products. Food Chemistry, 82, 235-242.

Je, J.Y., Park., P.J., Kwon, J.Y. \& Kim, S.K. (2004). A novel angiotensin I converting enzyme inhibitory peptide from Alaska pollack (Theragra chalcogramma) frame protein hydrolysate. Journal of Agriculture and Food Chemistry, 52, 7842-7845.

Je, J.-Y., Qian, Z.-J., Byun, H.-G. \& Kim, S.-K. (2007). Purification and characterization of an antioxidant peptide obtained from tuna backbone protein by enzymatic hydrolysis. Process Biochemistry, 42, 840-846.

Jung Nim, P., Watanabe, T., Endoh, K., Watanabe, K. \& Abe, H. (2002). Taste-active components in a Vietnamese fish sauce. Fisheries Science, 68, 913-920.

Jung, W.J., Kuk, J.H., Kim, K.Y. \& Park, R.D. (2005). Demineralization of red crab shell waste by lactic acid fermentation. Applied Microbiology and Biotechnology, 67, 851854.

Jung, W.K. \& Kim, S.K. (2007). Calcium-binding peptide derived from pepsinolytic hydrolysates of hoki (Johnius belengerii) frame. European Food Research and Technology, 224, 763-767.

Kechaou E.S., D.J., Donnay-Moreno C., Jaouen P., Gouygou J-P., Bergé J-P. \& Ben Amar R. (2009). Enzymatic hydrolysis of cuttlefish (Sepia officinalis) and sardine (Sardina pilchardus) viscera using commercial proteases: Effects on lipid distribution and amino acid composition. Journal of Bioscience and Bioengineering, 107, 158-164.

Kristinsson, H.G. \& Rasco, B.A. (2000). Biochemical and functional properties of Atlantic salmon (Salmo salar) muscle proteins hydrolyzed with various alkaline proteases. Journal of Agricultural and Food Chemistry, 48, 657-666.

Liceaga-Gesualdo, A.M. \& Li-Chan, E.C.Y. (1999). Functional properties of fish protein hydrolysate from herring (Clupea harengus). Journal of Food Science, 64, 10001004

Limam Z., Sadok S. \& El Abed A. (2008). Enzymatic Hydrolysis of Shrimp Head Waste: Functional and Biochemical Properties. Food Biotechnology, 22, (4): 352 - 362.

Mission Economique de Tananarive. (2008). Le secteur halieutique à Madagascar. Retrieved from ubifrance website: http://www.ubifrance.fr/peche-et-aquaculture-et-produitstransformes/userdocument.axd?id=001b0843720a

Official Methods of Analysis of AOAC International. (2005). AOAC International. Washington, USA, Secs 930.15.

Oliveira Cavalheiro, J.M., Oliveira de Souza, E. \& Bora, P.S. (2007). Utilization of shrimp industry waste in the formulation of tilapia (Oreochromis niloticus Linnaeus) feed. Bioresource Technology, 98, 602-606. 
Pacheco, N., Garnica-González, M., Ramírez-Hernández, J.Y., Flores-Albino, B., Gimeno, M., Bárzana, E. \& Shirai, K. (2009). Effect of temperature on chitin and astaxanthin recoveries from shrimp waste using lactic acid bacteria. Bioresource Technology, 100, 2849-2854.

Paulino, A.T., Simionato, J.I., Garcia, J.C. \& Nozaki, J. (2006). Characterization of chitosan and chitin produced from silkworm crysalides. Carbohydrate Polymers, 64, 98-103.

Pillai, C.K.S., Paul, W. \& Sharma, C.P. (2009). Chitin and chitosan polymers: Chemistry, solubility and fiber formation. Progress in Polymer Science, 34, 641-678.

Plascencia-Jatomea, M., Olvera-Novoa, M.A., Arredondo-Figueroa, J.L., Hal, G.M. \& Shirai, K. (2002). Feasibility of fishmeal replacement by shrimp head silage protein hydrolysate in Nile tilapia (Oreochromis niloticus L) diets. Journal of the Science of Food and Agriculture, 82, 753-759.

Rao, M.S., Munoz, J.H. \& Stevens, W.F. (2000). Critical factors in chitin production by fermentation of shrimp biowaste. Applied Microbiology and Biotechnology, 54, 808813.

Ravallec-Plé, R. \& Van Wormhoudt, A. (2003). Secretagogue activities in cod (Gadus morhua) and shrimp (Penaeus aztecus) extracts and alcalase hydrolysates determined in AR4-2J pancreatic tumour cells. Comparative Biochemistry and Physiology, Part B: Biochemistry and Molecular Biology, 134, 669-679.

Ruttanapornvareesakul, Y., Ikeda, M., Hara, K., Osako, K., Orawan, K. \& Nozaki, Y. (2005). Effect of shrimp head protein hydrolysates on the state of water and denaturation of fish myofibrils during dehydration. Fisheries Science, 71, 220-228.

Ruttanapornvareesakul, Y., Ikeda, M., Hara, K., Osatomi, K., Osako, K., Kongpun, O. \& Nozaki, Y. (2006). Concentration-dependent suppressive effect of shrimp head protein hydrolysate on dehydration-induced denaturation of lizardfish myofibrils. Bioresource Technology, 97, 762-769.

Sachindra, N.M. \& Mahendrakar, N.S. (2005). Process optimization for extraction of carotenoids from shrimp waste with vegetable oils. Bioresource Technology, 96, 1195-1200.

Sachindra, N.M., Bhaskar, N \& Mahendrakar, N.S. (2006). Recovery of carotenoids from shrimp waste in organic solvents. Waste Management, 26, 1092-1098.

Sagheer, F.A.A., Al-Sughayer, M.A., Muslim, S. \& Elsabee, M.Z. (2009). Extraction and characterization of chitin and chitosan from marine sources in Arabian Gulf. Carbohydrate Polymers, 77, 410-419.

Sathivel, S., Bechtel, P.J., Babbitt, J., Smiley, S., Crapo, C., Reppond, K.D. \& Prinyawiwatkul, W. (2003). Biochemical and functional properties of herring (Clupea harengus) byproduct hydrolysates. Journal of Food Science, 68, 2196-2200.

Sathivel, S., Smiley, S., Prinyawiwatkul, W. \& Bechtel, P.J. (2005). Functional and nutritional properties of red salmon (Oncorhynchus nerka) enzymatic hydrolysates. Journal of Food Science, 70, 401-406.

Simpson, B.K. \& Haard, N.F. (1985). The use of proteolytic enzymes to extract Carotenoproteins from shrimp wastes. Journal of Applied Biochemistry, 7, 212-222.

Slizyte, R.; Dauksas, E.; Falch, E.; Storrø, I. \& Rustad, T. (2005). Yield and composition of different fractions obtained after enzymatic hydrolysis of cod (Gadus morhua) byproducts. Process Biochemistry, 40, 1415-1424.

Steinhardt, H. \& Beychok, S. (1964). Interaction of protein with hydrogen ions and other smalle ions and molecules. In: Neurath H., editor. The proteins, vol 2. (139-304). New York: Academic Press.

Synowiecki, J. \& Al-Khateeb, N.A.A.Q. (2000). The recovery of protein hydrolysate during enzymatic isolation of chitin from shrimp Crangon crangon processing discards. Food Chemistry, 68, 147-152.

Thiansilakul, Y., Benjakul, S. \& Shahidi, F. (2007). Compositions, functional properties and antioxidative activity of protein hydrolysates prepared from round scad (Decapterus maruadsi). Food Chemistry, 103, 1385-1394.

Weil, J.-H. (2005). Biochimie générale [General Biochemistry]. Paris: DUNOD ed.. 
Yen, M.-T., Yang, J.-H. \& Mau, J.-L. (2009). Physicochemical characterization of chitin and chitosan from crab shells. Carbohydrate Polymers, 75, 15-21.

Zhao, Q.Y., Sannier, F. \& Piot, J.M. (1996). Kinetics of apperance of four hemorphins from bovine hemoglobin peptic hydrolysates by HPLC coupled with photodiode array detection. Biochimica et Biophysica Acta, 1295, 73-80.

\section{Tables}

Table 1: Chemical composition of fractions of hydrolysed shrimp head with commercial enzyme, $\mathrm{g} / 100 \mathrm{~g}$ on dry basis.

Tabla 1: Composición química de las fracciones de cabezas de gamba hidrolizadas con enzima comercial, $\mathrm{g} / 100 \mathrm{~g}$ en base seca.

\begin{tabular}{llllll}
\hline Fractions & Enzyme & $\begin{array}{l}\text { Protein } \\
(\%)\end{array}$ & $\begin{array}{l}\text { Lipid } \\
(\%)\end{array}$ & $\begin{array}{l}\text { Ash } \\
(\%)\end{array}$ & $\begin{array}{l}\text { Chitin } \\
(\%)\end{array}$ \\
\hline Soluble & Pepsin & $48.12 \pm 1.57$ & $1.17 \pm 0.34$ & $41.1 \pm 0.46$ & 9.61 \\
& Novozym 37020 & $51.59 \pm 0.01$ & $3.01 \pm 2.28$ & $32.93 \pm 0.06$ & 12.47 \\
& Protex 6L & $63.86 \pm 0.21$ & $3.81 \pm 0.21$ & $23.86 \pm 0.27$ & 8.47 \\
& Delvolase & $64.73 \pm 0.83$ & $3.57 \pm 0.02$ & $28.62 \pm 0.93$ & 3.08 \\
\hline Insoluble & Pepsin & $29.57 \pm 0.29$ & $36.20 \pm 0.32$ & $20.31 \pm 0.12$ & 13.92 \\
& Novozym 37020 & $47.14 \pm 0.32$ & $29.19 \pm 1.02$ & $9.24 \pm 0.62$ & 14.44 \\
& Protex 6L & $29.44 \pm 0.27$ & $24.31 \pm 1.11$ & $36.80 \pm 0.56$ & 9.45 \\
& Delvolase & $29.19 \pm 0.96$ & $20.82 \pm 0.94$ & $30.79 \pm 0.16$ & 14.20 \\
\hline
\end{tabular}


Table 2: Amino acid composition in raw material and hydrolysates, $\mathrm{mg} / \mathrm{g}$ on dry weight basis.

Tabla 2: Composición en aminoácidos para la materia prima y los hidrolizados, $\mathrm{mg} / \mathrm{g}$ en base seca.

\begin{tabular}{|c|c|c|c|c|c|}
\hline Amino acid & Raw materia & al Pepsin & $\begin{array}{l}\text { Novozym } \\
37020\end{array}$ & Protex 6L & Delvolase \\
\hline Leucine & 15.72 & 22.27 & 19.65 & 35.37 & 24.89 \\
\hline Phenylalanine & 11.55 & 18.15 & 3.30 & 24.75 & 18.15 \\
\hline Valine & 9.36 & 12.87 & 16.38 & 24.57 & 19.89 \\
\hline Lysine & 8.76 & 17.52 & 16.06 & 16.06 & 11.68 \\
\hline Isoleucine & 7.86 & 14.41 & 13.10 & 23.58 & 18.34 \\
\hline Threonine & 5.95 & 10.71 & 15.47 & 20.23 & 14.28 \\
\hline Histidine & 1.55 & 4.65 & 6.20 & 0.00 & 6.20 \\
\hline Methionine & 1.49 & 4.47 & 0.00 & 10.43 & 7.45 \\
\hline Essential amino acids (EAA) & 62.24 & 105.05 & 90.16 & 154.99 & 120.88 \\
\hline Glutamic acid & 24.99 & 39.69 & 39.69 & 60.27 & 49.98 \\
\hline Alanine & 21.36 & 26.70 & 16.91 & 32.04 & 24.03 \\
\hline Aspartic acid & 21.28 & 41.23 & 23.94 & 43.89 & 35.91 \\
\hline Glycine & 18.75 & 21.00 & 28.50 & 35.25 & 27.75 \\
\hline Proline & 17.25 & 21.85 & 24.15 & 27.60 & 24.15 \\
\hline Tyrosine & 7.24 & 10.86 & 5.43 & 18.10 & 7.24 \\
\hline Serine & 4.20 & 4.20 & 9.45 & 16.80 & 13.65 \\
\hline Non essential amino acids (NEAA) & ) 115.07 & 165.53 & 148.07 & 233.95 & 182.71 \\
\hline \%EAA & 35.10 & 38.82 & 37.85 & 39.85 & 39.82 \\
\hline EAA/NEAA & 0.54 & 0.63 & 0.61 & 0.66 & 0.66 \\
\hline
\end{tabular}




\section{Figures}

Figure 1: Hydrolysis process flow diagram.

Figura 1: Organigrama del proceso de hidrólisis.

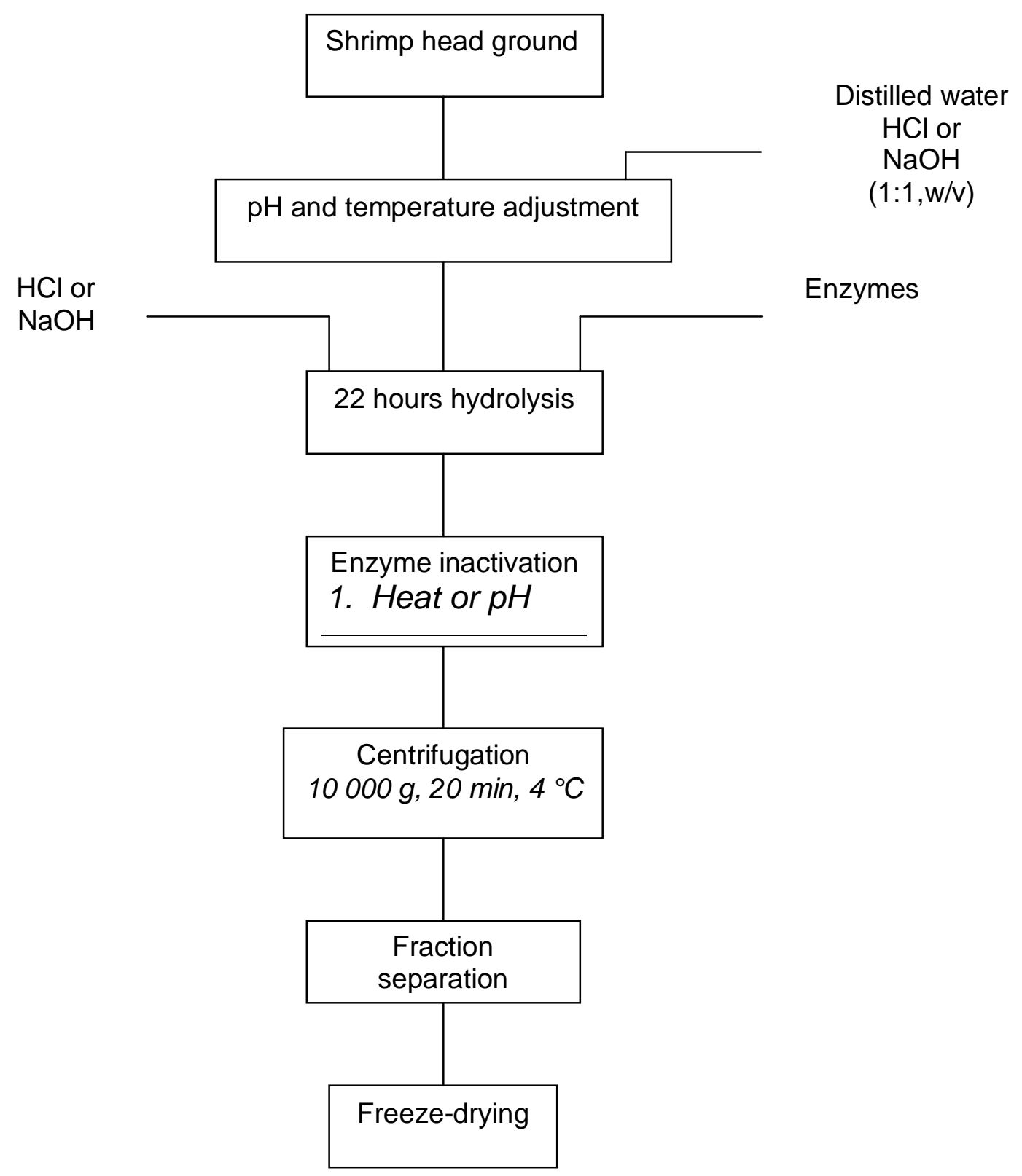


Figure 2: 22 hours hydrolysis curves of shrimp head with commercial enzymes.

Figura 2 : Curvas de la hidrólisis de 22 horas de cabezas de gamba con enzimas comerciales.

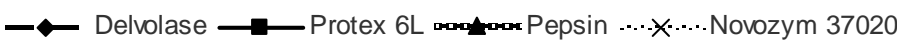

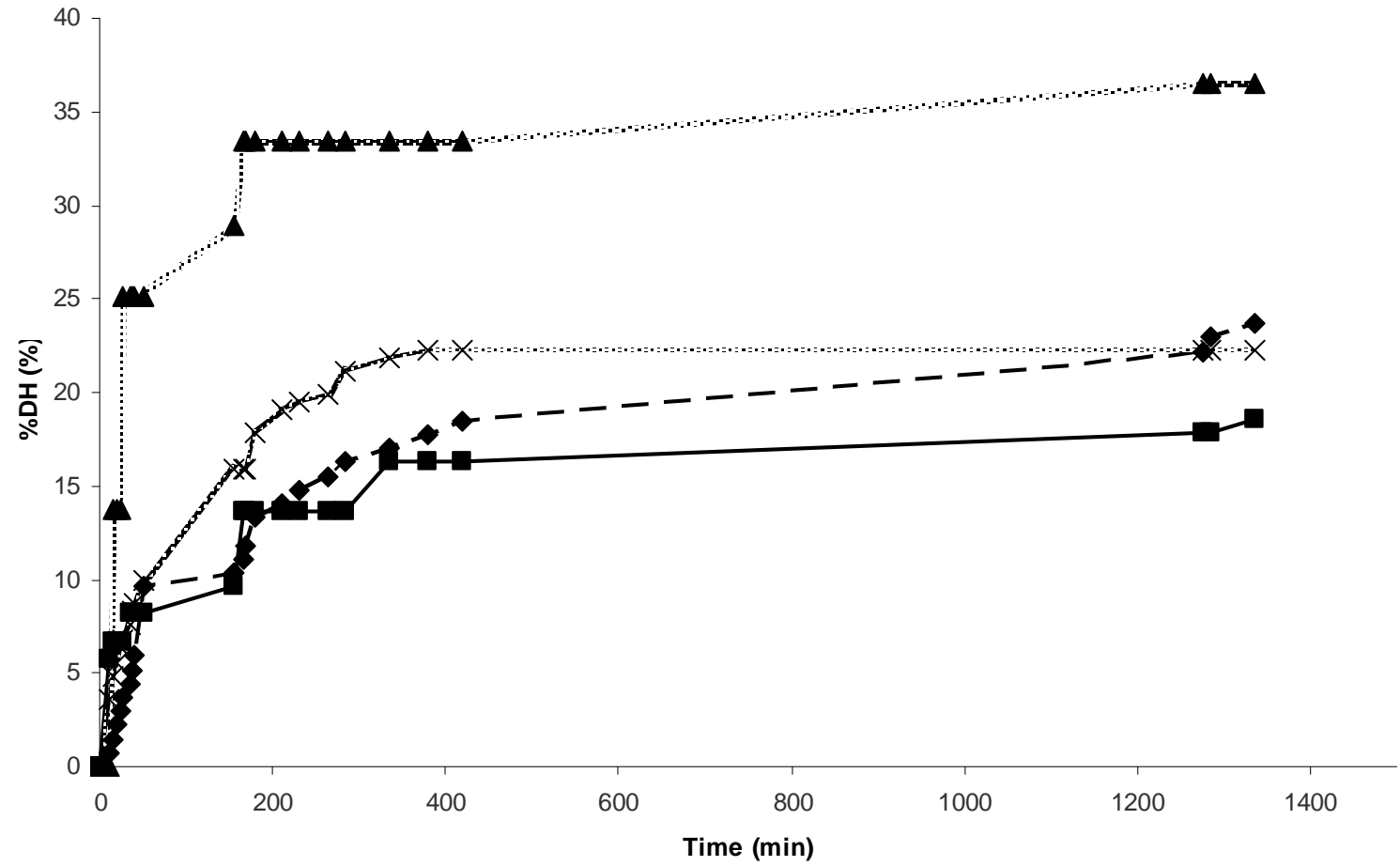

Figure 3: Dry matter distribution in supernatant and sludge after 22 hours of hydrolysis of shrimp head with commercial enzymes.

Figura 3: Distribución de la materia seca en el sobrenadante y residuo después de 22 horas de hidrólisis de cabezas de gamba con enzimas comerciales.

\section{$\square$ Supernatant $\square$ Sludge}

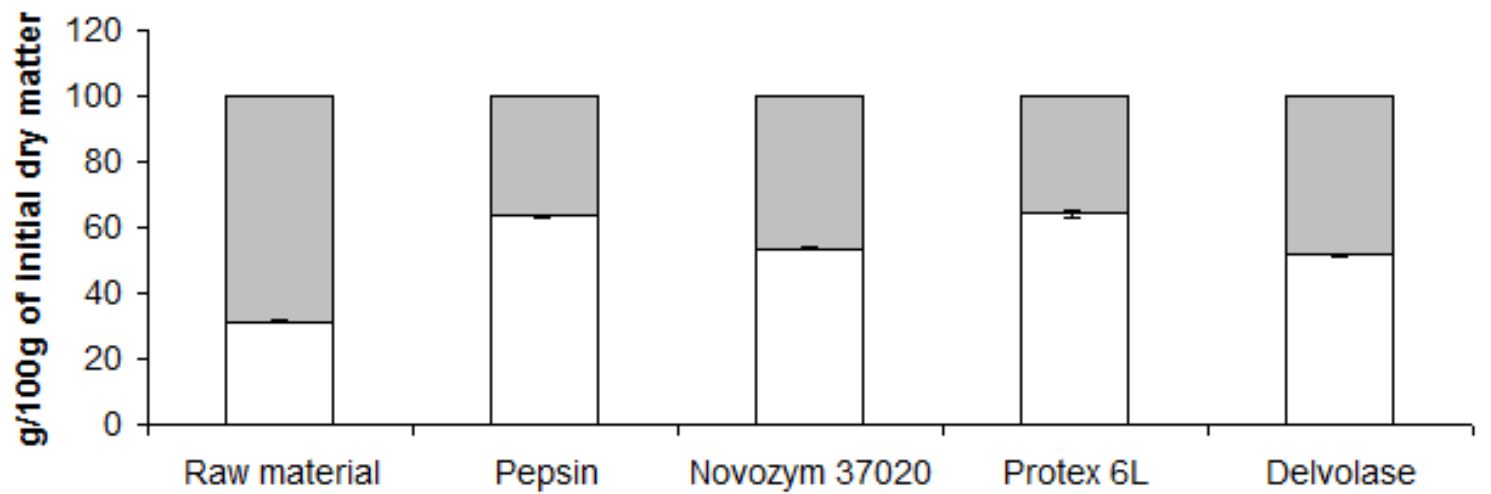


Figure 4: Nitrogen distribution in supernatant and sludge after 22 hours of hydrolysis of shrimp head with commercial enzymes.

Figura 4: Distribución de Nitrógeno en el sobrenadante y residuo después de 22 horas de hidrólisis de cabezas de gamba con enzimas comerciales.

$\square$ Supernatant $\square$ Sludge

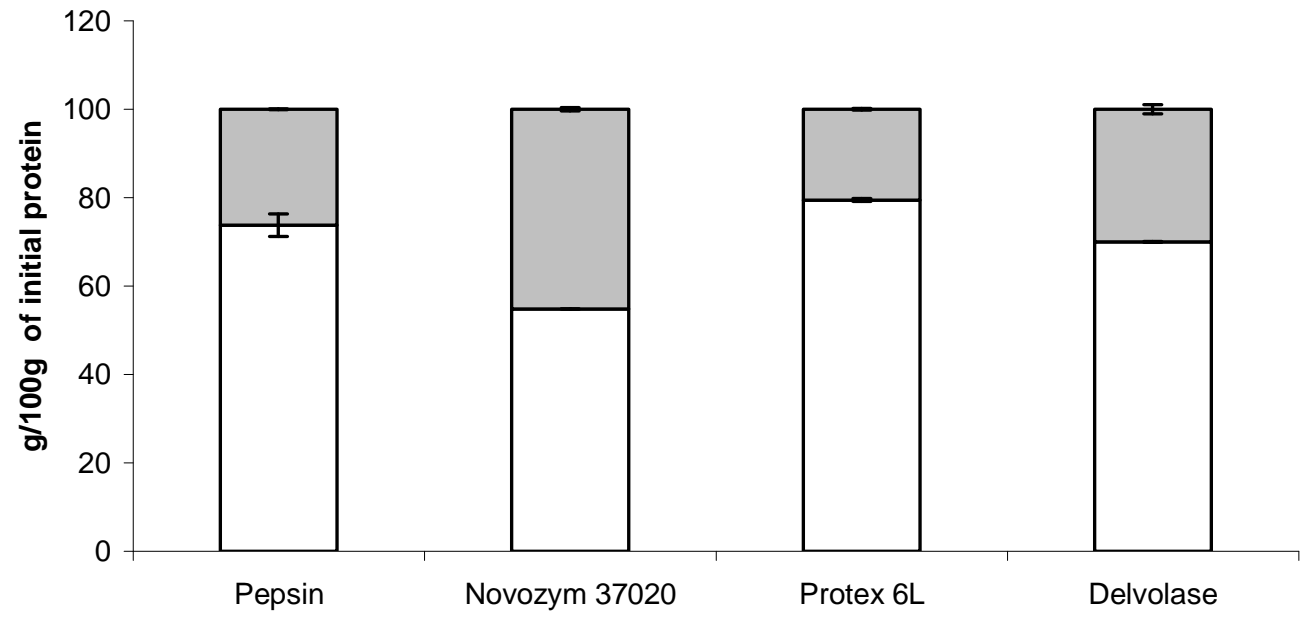

Figure 5: Chromatogram of shrimp head hydrolysate with Pepsin.

Figura 5: Cromatograma de hidrolizado de cabeza de gamba con Pepsina.

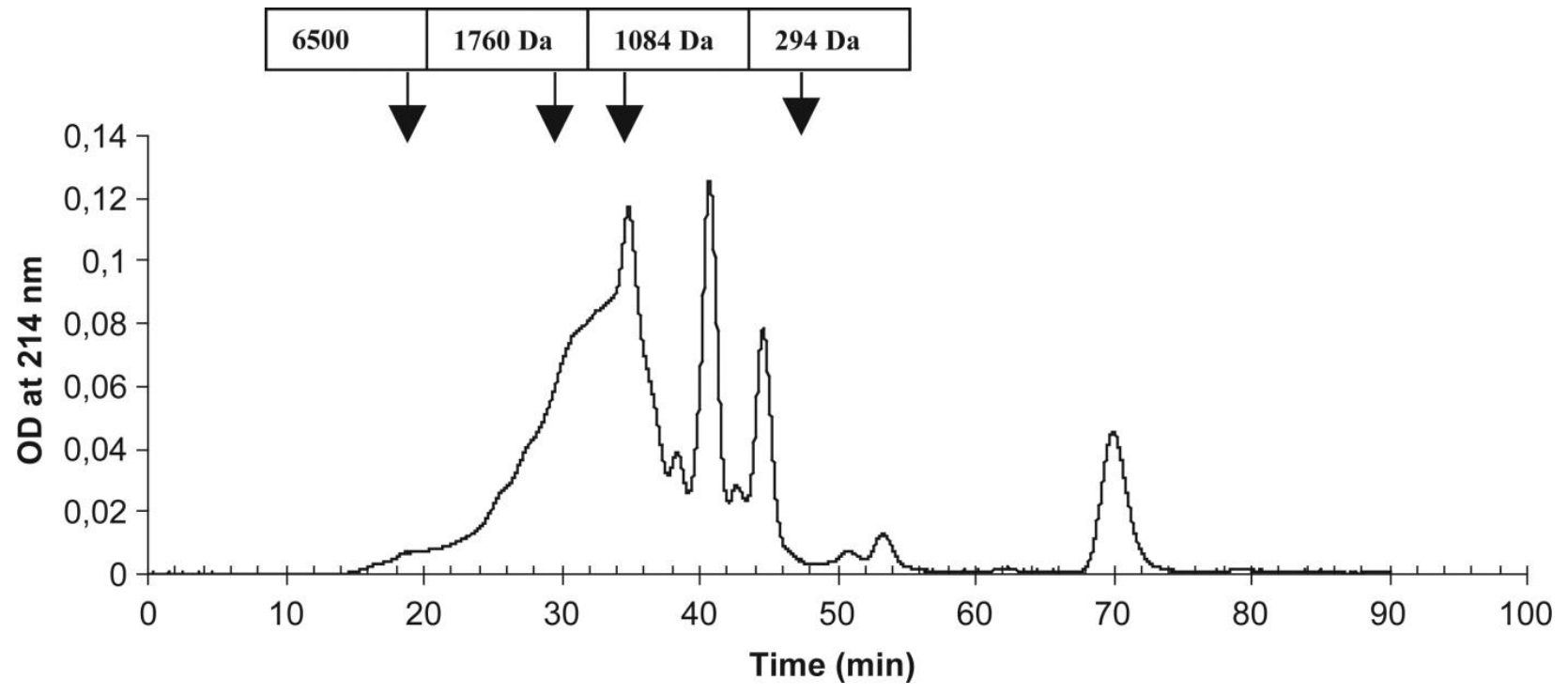


Figure 6: Peptides molecular weight distribution in hydrolysates.

Figura 6: Distribución de pesos moleculares en los hidrolizados.

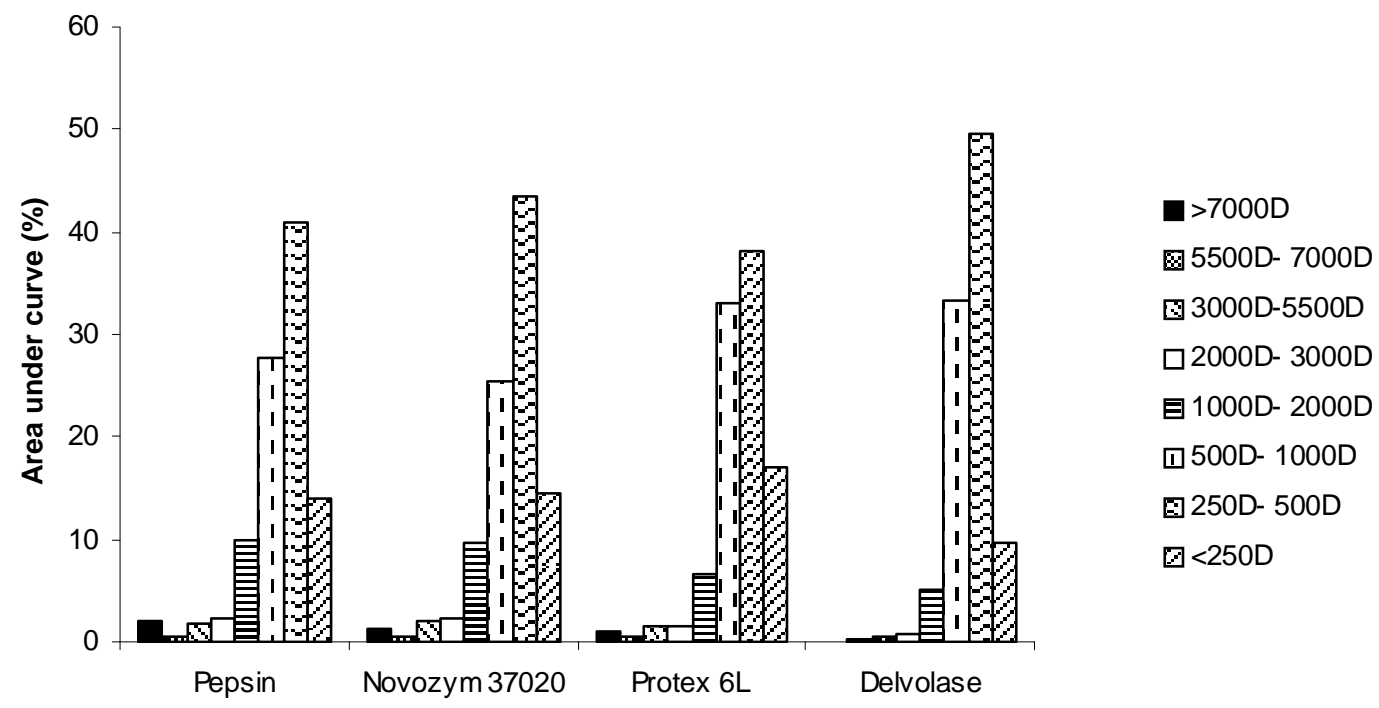


Supplementary Table 1. Physico-chemical characteristics (ash and gluten content, gluten index) of meals, dough alveographic indices ( $W$ and $P / L)$, and pasta value (PV- $K$ ) calculated according to the Equation (1). Tabla adicional 1. Características fisico-químicas (ceniza y contenido de gluten, indice de gluten) de harinas, índices alveográficos de masa (W y $P / L)$ y valores de pasta (PV- $K$ ) calculados según la ecuación (1).

\begin{tabular}{|c|c|c|c|c|c|c|c|}
\hline Meal mixtures & Ash ( $\mathrm{g} \mathrm{kg}^{-1}$ dry weight) & Gluten ( $\mathrm{g} \mathrm{kg}^{-1}$ dry weight) & Gluten Index & $b^{*}$ & $w(\mathrm{~J})$ & $P / L\left(\right.$ Pa $\left.\mathrm{mm}^{-1}\right)$ & $\mathrm{PV}-\mathrm{K}$ \\
\hline Semolina & $8.3 \pm 0.2 a$ & $100 \pm 2 d$ & $80 \pm 2 a$ & $21.6 \pm 0.30 \mathrm{~h}$ & $146 \pm 2 f$ & $2.02 \pm 0.00 a$ & $34.8 \pm 1.2 \mathrm{a}$ \\
\hline $5 \%$ TDWM-semolina & $8.6 \pm 0.2 a$ & $94 \pm 2 c$ & $89 \pm 3 c$ & $16.5 \pm 0.22 f$ & $143 \pm 2 f$ & $2.29 \pm 0.10 \mathrm{~b}$ & $33.5 \pm 1.0 \mathrm{~b}$ \\
\hline $10 \%$ TDWM-semolina & $9.0 \pm 0.1 \mathrm{~b}$ & $93 \pm 1 \mathrm{c}$ & $87 \pm 2 b, c$ & $14.8 \pm 0.13 f$ & $124 \pm 4 d$ & $3.59 \pm 0.15 \mathrm{c}$ & $28.3 \pm 1.5 \mathrm{c}$ \\
\hline 15\% TDWM-semolina & $9.3 \pm 0.2 b$ & $92 \pm 3 c$ & $85 \pm 2 b, c$ & $13.2 \pm 0.12 \mathrm{e}$ & $133 \pm 1 \mathrm{e}$ & $4.88 \pm 0.20 \mathrm{~d}$ & $17.6 \pm 1.7 \mathrm{~d}$ \\
\hline 20\% TDWM-semolina & $9.6 \pm 0.2 b$ & $92 \pm 2 c$ & $85 \pm 2 b, c$ & $12.5 \pm 0.05 d$ & $114 \pm 1 \mathrm{c}$ & $5.71 \pm 0.35 e$ & $6.3 \pm 1.6 \mathrm{e}$ \\
\hline 30\% TDWM-semolina & $10.2 \pm 0.2 \mathrm{c}$ & $88 \pm 1 c$ & $84 \pm 1 b$ & $11.5 \pm 0.06 \mathrm{c}$ & $72 \pm 2 b$ & $9.54 \pm 0.10 f$ & \\
\hline 40\% TDWM-semolina & $10.9 \pm 0.3 \mathrm{~d}$ & $81 \pm 2 b$ & $83 \pm 2 b$ & $10.7 \pm 0.20 \mathrm{~b}$ & $55 \pm 3 a$ & $11.45 \pm 0.10 \mathrm{~g}$ & \\
\hline $50 \%$ TDWM-semolina & $11.9 \pm 0.5 \mathrm{e}$ & $77 \pm 0 a$ & $89 \pm 3 c$ & $10.8 \pm 0.20 \mathrm{~b}$ & n.d. & n.d. & \\
\hline TDWM & $15.6 \pm 0.3 f$ & n.d. & $97 \pm 3 d$ & $9.8 \pm 0.37 a$ & n.d. & n.d. & \\
\hline
\end{tabular}

Note: n.d., not determinable.

Within each column, different letters indicate significant differences $(P<0.05)$.

Nota: n.d., no determinado.

En cada columna, letras diferentes indican diferencias significativas $(P<0.05)$

Supplementary Table 2. Physico-chemical characteristics and optimal cooking time (OCT) of spaghetti made of semolina and TDWM.

Tabla adicional 2. Características fisico-químicas y tiempo óptimo de cocido (OCT) de espaguetis hechos con semolina y harina de trigo duro tostado.

\begin{tabular}{|l|}
\hline Spaghetti samples \\
\hline Semolina \\
\hline $5 \%$ TDWM-semolina \\
\hline $10 \%$ TDWM-semolina \\
\hline $15 \%$ TDWM-semolina \\
\hline $20 \%$ TDWM-semolina \\
\hline $30 \%$ TDWM-semolina \\
\hline
\end{tabular}

\begin{tabular}{|l|c|} 
& Moisture $\left(\mathrm{g} \mathrm{kg}^{-\mathbf{1}}\right)$ \\
\hline $64.0 \pm 2.9 \mathrm{a}$ \\
\hline $65.5 \pm 4.0 \mathrm{a}$ \\
\hline $63.7 \pm 1.6 \mathrm{a}$ \\
\hline $70.2 \pm 5.3 \mathrm{a}$ \\
\hline $61.0 \pm 8.9 \mathrm{a}$ \\
\hline $66.0 \pm 3.2 \mathrm{a}$
\end{tabular}

\begin{tabular}{|l|}
\hline \multicolumn{1}{|c|}{$\boldsymbol{a}_{\boldsymbol{w}}$} \\
\hline $0.51 \pm 0.01 \mathrm{c}$ \\
\hline $0.47 \pm 0.00 \mathrm{~b}$ \\
\hline $0.46 \pm 0.00 \mathrm{a}$ \\
\hline $0.47 \pm 0.02 \mathrm{~b}$ \\
\hline $0.47 \pm 0.00 \mathrm{~b}$ \\
\hline $0.47 \pm 0.02 \mathrm{~b}$
\end{tabular}

\begin{tabular}{|l|l|}
\multicolumn{1}{|c|}{$L *$} & \multicolumn{1}{|c|}{$\mathrm{a}^{*}$} \\
\hline $61.32 \pm 0.44 \mathrm{e}$ & $2.3 . \pm 0.43 \mathrm{~b}, \mathrm{c}$ \\
\hline $44.86 \pm 1.15 \mathrm{~d}$ & $4.47 \pm 0.22 \mathrm{e}$ \\
\hline $36.50 \pm 1.83 \mathrm{c}$ & $3.56 \pm 0.23 \mathrm{~d}$ \\
\hline $31.78 \pm 2.16 \mathrm{~b}$ & $2.41 \pm 0.11 \mathrm{c}$ \\
\hline $30.89 \pm 0.70 \mathrm{a}, \mathrm{b}$ & $1.83 \pm 0.06 \mathrm{~b}$ \\
\hline $29.11 \pm 0.77 \mathrm{a}$ & $1.07 \pm 0.06 \mathrm{a}$ \\
\hline
\end{tabular}

\begin{tabular}{|l|l|}
\multicolumn{1}{|c|}{$b^{*}$} \\
\hline $36.93 \pm 0.31 \mathrm{e}$ \\
\hline $19.74 \pm 1.12 \mathrm{~d}$ \\
\hline $9.72 \pm 0.83 \mathrm{c}$ \\
\hline $5.29 \pm 0.37 \mathrm{~b}$ \\
\hline $4.90 \pm 0.09 \mathrm{~b}$ \\
\hline $3.36 \pm 0.22 \mathrm{a}$ \\
\hline
\end{tabular}

$390 \pm 20 a$,

$390 \pm 20 a, b$

Note: Within the same column, different letters indicate significant differences $(P<0.05)$.

Nota: En cada columna, letras diferentes indican diferencias significativas $(P<0.05)$ 